\title{
Genetic Improvement of Wheat for Biotic and Abiotic Stress Tolerance
}

\author{
Omkar M. Limbalkar, Vijay K. Meena, Mandeep Singh* and V.P. Sunilkumar \\ Division of Genetics, ICAR-Indian Agricultural Research Institute, New Delhi 110012, India \\ *Corresponding author
}

\begin{tabular}{|c|c|}
\hline & A B S T R A C T \\
\hline $\begin{array}{l}\text { Ke y w o r d s } \\
\text { Wheat, Biotic and } \\
\text { abiotic stress, } \\
\text { Tolerance }\end{array}$ & \multirow{3}{*}{$\begin{array}{l}\text { The higher wheat grain production will be needed to meet the demand of ever growing } \\
\text { population which can be achieved by increasing the productivity and reducing the losses } \\
\text { caused by biotic and abiotic stresses. All the three rusts along with Karnal bunt and loose } \\
\text { smut in favorable environments causing significant yield losses in wheat. The major } \\
\text { abiotic stresses affecting wheat are heatstress and drought which has significant impact on } \\
\text { wheat production, hence developing resistant/tolerant wheat cultivars is the most eco- } \\
\text { efficient approach for management of biotic and biotic stresses therefore the genetics of } \\
\text { resistance/tolerance is having prime importance for genetic improvement of wheat which } \\
\text { is tried to review in this article. }\end{array}$} \\
\hline Article Info & \\
\hline $\begin{array}{l}\text { Accepted: } \\
\text { 15 November } 2018 \\
\text { Available Online: } \\
10 \text { December } 2018\end{array}$ & \\
\hline
\end{tabular}

\section{Introduction}

Wheat is a major staple food crop being consumed by 30 percent population of the world (Eversole et al., 2014) and is grown in all the continents. Globally wheat is grown on 219.70 million hectares area with production of $755.2 \mathrm{mt}$ (Source: USDA, 2017) while in India cultivated on an area of 30.60 million hectares with production of $98.61 \mathrm{mt}$, with highest ever productivity of 3.22 t/ha according to $3^{\text {rd }}$ advance estimate (2017-18) of government of India. In India, wheat comes next to rice in terms of production and plays an important role in food security through a sizeable portion in the buffer stock, placing India to second largest producer of wheat in the world (Source: USDA, 2017). In India, sizeable area under wheat cultivation is confined to northern states like Uttar Pradesh, Madhya Pradesh Punjab, Haryana, Gujarat, Rajasthan, and Bihar. Conversely, in view of growing population, we need higher grain yield in the future may be through increase in productivity and reducing the losses caused by abiotic and biotic stresses. The major biotic stress in wheat production includes diseases like rust, Karnal bunt, loose smut, powdery mildew and blast (Prescott et al., 1986).

Among several pathogens damaging wheat crop, rust pathogens are the most prevalent. They are reported from all wheat growing countries (Roelfs et al., 1992) and causes a severe damage to the wheat production worldwide. It includes leaf rust (Puccinia triticina), stem rust $(P$. graminis tritici) and 
stripe rust ( $P$. striiformis). All the rust pathogens are obligate parasite in nature and have specific host range. Severe epidemics have been reported by all the three rusts in favorable environments (Roelfs et al., 1992) causing significant yield losses which were recorded in some counties. Losses due to rust diseases ranges from 15-20 percent worldwide, which accounts nearly 20-30 mt of grain yield (Hanson et al., 1982).

In case of abiotic stress, wheat cultivars are affected by stress due to moisture, salt, temperature and micronutrient. Continued experience to high temperatures in rainfed areas of the globe, may lead to drought stress. Prolonged high temperature may leads to osmotic stress as rapid evaporation of water from soils resulting in higher salt concentrations. A meta-analysis of 1,700 published simulations (Challinor et al., 2014) estimated a significant level of yield loss in wheat with each $2^{\circ} \mathrm{C}$ rise of temperature in temperate and tropical regions. Asseng et al., (2015) reported that decrease in $6 \%$ for every ${ }^{\circ} \mathrm{C}$ rise in temperature in wheat production which is equivalent to a reduction of about 42 Mt globally. Therefore the major challenge of today's agriculture is to maintain crop productivity levels to mitigate the need of growing population under limited resources. Conventional breeding for improving stress tolerance in crop is not only time and labor consuming but involves multigene families that govern the molecular and physiological mechanisms. Hence molecular plant breeding has great role in the improvement of crops for stress tolerance.

\section{Genetic basis of disease resistance}

\section{Wheat rust}

In India, all the three types of rusts are known to be present in different agro-climatic regions. Yellow or stripe rust of wheat
(Puccinia striiformis) is more common in cooler areas of Northern India. Black or stem rust of wheat (P. graminis Pers. f. sp. Tritici Eriks \& Henn.) is restricted to Peninsular and Central India (Joshi et al., 1976). Among all the rusts, brown or leaf rust $(P$. triticina Eriks.) is widespread and affect the wheat crop where ever it is grown (Roelfs, 1992). The various adaptive range of this pathogen in different climatic conditions adds to its potential to predominant for the crop losses (Roelfs et al., 1992). Leaf rust perhaps results in major losses due to more number of infection cycles in the favorable environment during crop growth and has potential to cause yield losses up to 50 percent, if infection starts at early growth stage (Huerta-Espino et al., 2011). The commonly distributed pathotypes of leaf rust (Puccinia triticina) across the country are 12-4, 12-5, 12-7, 77-1, 77-2, 77-5, 77-9, 104A, 104-2 and 104-3, $162 \mathrm{~A}, 162-1$ and 162-2 whereas, in stem rust pathotype 21-1, 40A, 40-1, 40-2, 117-A, 1171, 117-2, 117-3 117-4 117-5 and 117-6 have been frequently identified. Pathotype 77-5 and 40A for leaf and stem rust respectively were the most predominant in the country.

Genetic studies on leaf rust resistance started about a century ago. So far 79 leaf rust resistance $(L r)$ genes have been designated in wheat (McIntosh et al., 2017).In India, from 1931 to 2015 about 120 new pathotypes have been reported in all three rusts of wheat. In leaf rust alone, 50 pathotypes have been reported in India during 1931-2011. Leaf rust resistance genes commonly exploited in Indian cultivars are $L r 1, L r 3, L r 9, L r 10, L r 13$, Lr14a, Lr17, Lr19, Lr23, Lr24, Lr26, Lr28, Lr34 and Lr46 (Bhardwaj et al., 2010; Tomar et al., 2014). Pathotype 77-5, most virulent and predominant in India and it knocks down most of the $T$. aestivum derived seedling leaf rust resistance genes (Tomar et al., 2014). Virulent pathotypes have also evolved against several alien genes such as Lr9 (Nayar et al., 
2003), Lr19 (Bhardwaj et al., 2005), Lr26 (Nayar et al., 1993) and Lr28 (Bhardwaj et al., 2010). Lr24 is the still effective in India, however, virulence for $\operatorname{Lr} 24$ has already been reported in several parts of the world (Singh, 1991).

Similarly stem rust resistance genes $S r 2$, Sr7a, Sr8a, Sr9b, Sr11, Sr13, Sr14, Sr21, Sr23, Sr24, Sr25, Sr28, Sr30, Sr31 and Sr36have been identified bread wheat cultivars in India. Of the stem rust resistance genes, $\operatorname{Sr} 31$ is effective against all the pathotypes in India, though emergence of Ug99 and its variants in several countries has made this gene vulnerable (Pretorius et al., 2000).Sr2 confers wide spectrum but moderate level of resistance at adult plant stage (Mishra et al., 2011; Tomar et al., 2014).

The resistance genes $L r 1, L r 3, L r 10, L r 13$, $L r 23$, and $L r 26$ are race-specific commonly found alone or incombination in Indian cultivars e.g. bread wheats; NIAW34, GW322, HS420, HD2329, VL832 and A-930-1, PDW233, PBW34 and GW1189 (durum wheat) exhibit adult plant resistance against one or more virulent and prevalent pathotypes 12-2, 77-5 and 104-2 (Bhardwaj et al., 2010). The wheat cultivars carrying gene Lr13+ or Lr13+Lr34+ combination showed adequate level of APR (Kulkarni et al., 1980).

Till date 57 stem rust resistance $(S r)$ genes have been designated in wheat (McIntosh et al., 2017) since genes Sr2, Srl1, Sr31 and Sr24 have been commonly used in Indian bread wheat cultivar; and $\mathrm{Sr} 2, \mathrm{Sr} 7 b, \mathrm{Sr} 9 e$, Srll and Srl2 in durum wheat (Nayar et al., 2001; Bhardwaj et al., 2011; Mishra et al., 2011). While the most frequent stripe rust resistance genes are $\mathrm{Yr} 2, \mathrm{Yr} 9, \mathrm{Yr} 18$ and $\mathrm{Yr} 27$. However, $Y r 27$ has been exploited commonly in some of the genotypes e.g. PBW343, HS490 and PBW373 (Anonymous, 2006).
Frequent evolution of virulent pathotypes forced the breeder to search for new sources of resistance. To enhance the diversity of resistance in cultivated varieties, secondary and tertiary gene pools of wheat are being exploited. The identification molecular marker(s) linked to the trait of interest will be useful in speeding up the breeding programme. The knowledge of affectivity of introgressed resistance to different pathotypes helps the breeder to design the breeding programme. Therefore effective gene deployment based on prevalence of pathotypes in a target geographical area by pyramiding the resistance genes helps to minimize the yield loss. Developing resistant wheat cultivars is the most efficient, economical, and environment friendly approach for management of rusts. However, rust is a dynamic pathogen and there is a rapid evolution of new pathotypes which can overcome the resistance in wheat cultivars.

\section{Karnal bunt}

Karnal bunt of wheat is caused by Neovossia indica Mundkur (Syn. Tilletia indica), and first reported in India by Mitra (1931), was considered as minor disease in country till 1968. However, the outbreak of disease occurred during 1969-70 and since then in the Indian subcontinent Karnal bunt has become a serious disease of wheat. It causes significant yield losses and deteriorates quality of grain (Fuentes-Dávila, 1995). It control by fungicides is not effective mainly due to it is soil, air and seed borne in nature. Therefore the most efficient method of disease control is developing resistant varieties.

Most of Aegilops spp. accessions were found to be resistant to Karnal bunt (Warham et al., 1986; Chhuneja et al., 2008). Resistance in synthetic hexaploid wheat has been derived from Aegilops tauschii and elite durum wheat cultivars and crosses of synthetic hexaploids 
with bread wheat cultivars (Mujeeb-Kazi et al., 2006). Fuentes-Dávila et al., (1995) reported six resistance genes $K b 1, K b 2, K b 3$, $K b 4, K b 5$, and $K b 6$ which can be effectively used in wheat breeding for disease resistance.

\section{Loose smut}

Loose smut, caused by the fungus Ustilago tritici (Pers.), is a seed-borne disease of wheat which is common and prevalent in all wheatgrowing regions of the world (Nielsen and Thomas, 1996).There are eight resistance genes have been reported so far against loose smut of wheat which were designated as Ut1, $U t 2, U t 3, U t 4, U t 5, U t 6, U t 7$ and Ut8 (Kassa et al., 2015).

\section{Genetics of abiotic stress tolerance}

Wheat is an important crop worldwide, providing 25\%-50\% of calorific needs of growing human population (Dixon et al., 2009). However, there has been a decline in the rate of growth in world wheat production and yields for several years during the present decade due to various reasons.In past 50 years wheat production and productivity have been significantly improved through exploitation of genes for plant resistance to biotic stresses, dwarfness and photoperiod insensitivity (Reynolds and Borlaug, 2006). However, further increase in wheat productivity only possible through the genetic improvement of cultivated wheat for abiotic stresses mainly like terminal heat tolerance and drought tolerance or else photosynthetic ability is enhanced through manipulation of ribulose1,5-bisphosphate carboxylase oxygenase (RUBISCO) (Reynolds et al., 2011).

\section{Major abiotic stresses}

Factors that influence yield outputs are various biotic and abiotic stress constraints augmented by environmental factors which adversely affect growth, metabolism, and yield. Drought, salinity, low and high temperatures, floods, pollutants, and radiation are the important stress factors limiting the productivity of crops (Lawlor and Cornic, 2002). There is sufficient genetic variation in the wheat gene pool that can be ensured for continued improvement of wheat adaptation to abiotic stress (Trethowan and MujeebKazi, 2008).

\section{Heat stress}

Wheat as a cool season crop, it has as an optimal growing temperature during reproductive stage of $15{ }^{\circ} \mathrm{C}$ and for every degree Celsius temperature above this optimum leads to reduction in yield of 3\%$4 \%$ has been observed (Wardlaw et al., 1989). However, it has been reported that the average worldwide temperature is increasing at a rate of $0.18{ }^{\circ} \mathrm{C}$ every ten years (Hansen et al. 2012). Thus, the likely impact of heat stress in wheat has recently attracted increasing attention (Moriondo et al., 2011). Heat stress causes injury to cellular structure and disturbs various metabolic pathways, specifically photosynthesis, membrane thermostability, and starch synthesis related pathways (Larkindale et al., 2002). Denaturation of proteins and increased levels of unsaturated fatty acids caused by heat stress disrupt water, ion, and organic solute movement across membranes, leading to increased cell membrane permeability, and in turn, inhibition of cellular function (Cossani et al., 2012).Temperature can modify developmental and growth rates in plants. Similarly, heat stress affects agronomic traits at every growth stage, but the before flowering stage and anthesis period are comparatively more sensitive to high temperature compared to after flowering stages.

Heat tolerance is a quantitative trait, controlled by a number of genes/QTL 
(quantitative trait loci). Over the last three decades' efforts have been made to reveal the genetic basis of heat tolerance. Langdon chromosome substitution lines were firstly used in mapping heat tolerance genes and associated genes were found on chromosomes 3A, 3B, 4A, 4B, and 6A in 1991 (Sun et al., 1991).

$\mathrm{Xu}$ et al., (1996) later reported that chromosomes 3A, 3B and 3D were associated with heat tolerance in wheat cultivar (cv) Hope. Using chromosome substitution lines between Chinese Spring and Hope, chromosomes 2A, 3A, 2B, 3B, and 4B of Hope significantly enhanced heat tolerance (Chen et al., 2007). Collectively, chromosomes $3 \mathrm{~A}$ and $3 \mathrm{~B}$ appeared to harbor key genes controlling heat tolerance in wheat.

Exploration and utilization of novel genetic variation is the priority for genetic improvement of heat tolerance in wheat breeding programs. In a study of > 1200 Mexican wheat landraces collected from areas with diverse thermal regimes, a highly significant correlation between leaf chlorophyll content and thousand grain weight was observed and a group of superior accessions were identified (Hede et al., 1999).

Populations of wild species frequently harbor high intra-species variation for tolerance traits that are superior to what is available in the modern cultivars. Indeed, Triticum dicoccoides and $T$. monococcum have been reported as potential sources of germplasms that can be used to enhance heat tolerance in bread wheat. Additionally, variable degrees of heat tolerance were observed in Aegilops speltoides, Ae. longissima and Ae. Searsii(Pradhan et al., 2012). However, only a small portion of the reported genetic variation in heat tolerance has been utilized due to limitations of conventional breeding methods.

\section{Drought stress}

The term "drought" defined as the absence of rainfall / irrigation for a period of time in which the plant water content reduced enough to interfere the plant processes (Tuberosa, 2012). Adverse environmental factors, of which water scarcity represents the most severe constraint to agriculture, account for about $70 \%$ of potential yield loses worldwide (Boyer, 1982). The most affected states in India are Rajasthan, parts of Gujarat, Haryana and Andhra Pradesh (Mitra, 2001). As drought persists, the conditions surrounding it gradually worsen and its impact on the local population gradually increases (Nath et al., 2017). Developing crop cultivars with improved drought resistance is considered as a sustainable and an economically viable approach to enhance crop productivity and ensure food security for the growing human population (Blum, 1988; Bennett et al., 2012).

Drought stress environments is complex, since each of these traits is controlled by many genes, each individual gene having a small effect (Blum et al., 1988). The genetic analysis of Canopy Temperature Depression under drought has been carried out and QTL for CT were reported on chromosomes $1 \mathrm{~B}$, 2B, 3B, and 4A (Pinto et al., 2008). Spielmeyer et al., (2007) reported QTL for early shoot vigor on chromosome arm 6AS of wheat. Genetic variability for green flag leaf area (GFLA) has been reported detected on chromosome 2D, the trait exhibits moderate heritability and seems to be under additive genetic control (Verma et al., 2004). GAsensitive dwarfing gene Rht8 was shown to reduce plant height without affecting coleoptile length or early vigor so that efforts are being made for the development of semi dwarf wheat genotypes suitable for cultivation in drier environments (Rebetzke et al., 2004). ABA is a stress hormone that accumulates in plant cells as a quick response to drought stress. Increased ABA makes the plant better 
adapted to water stress conditions (Mizrahi et al., 1974). Quarrie et al., (1994) later reported a QTL for drought-induced ABA accumulation on $5 \mathrm{~A}$ using single chromosome substitutions from a high ABA-genotype Ciano 67 into low ABA genotype Chinese Spring. Genetic variability for root traits has been reported in durum wheat the major QTL for seminal root traits were reported on $2 \mathrm{AL}$, 7AL and 7BL chromosome arms through association mapping (Sanguineti et al., 2007). Traits like canopy temperature depression, shoot vigor, stay green habit and stomatal conductance provides an improvement of wheat genotypes under both drought and heat stress. Seedling emergence, coleoptile length, GA-sensitive dwarf-ness, root vigor and architecture responsible for development of good wheat cultivars under drought stress.

In conclusion, application of chemical fungicides and pesticides can control pest and diseases to some extent but they are costly and environmentally undesirable measures while controlling abiotic stress cumbersome agronomic practice have to follow. The development resistant/ tolerant varieties based on its own defense mechanisms will be the most suitable approach for sustaining agricultural production and to improve environment and health. Understanding the genetics of resistance or tolerance is important so as to improve the efficiency of practical application of resistance genes/QTLs in wheat breeding program. The new technological development, like highthroughput DNA sequencing and microarray analysis, these advances facilitate the mapping and cloning of major genes and QTLs which eventually help in developing resistant/ tolerant cultivars of wheat for biotic and abiotic stress. Genomic information about both host plants and pests and pathogens should accelerate the rate of discovery of resistance genes. Transcript profiling techniques will allow the simultaneous examination of thousands of genes, and can be utilized to study changes in gene expression that are transcriptionally regulated in different environmental conditions. Ahead of transcript profiling, genomics also facilitates the functional analysis of genes associated with resistance and susceptibility. Therefore understanding the genetic nature of biotic and abiotic stress resistance/ tolerance respectively is important to combat with upcoming problems of maintaining the crop productivity in changing environment.

\section{References}

Anonymous. (2006). Report of the Coordinated Experiments- Vol III, 2006, Crop Protection (Eds. AK Sharma, DP Singh, MS Saharan, AK Singh, KS Babu and B Mishra). AICW \& BIP, Directorate of Wheat Research, Karnal, India, pp. 195.

Asseng, S., Ewert, F., Martre, P., Rötter, R. P., Lobell, D. B., Cammarano, D., Reynolds, M. P. (2015). Rising temperatures reduce global wheat production. Nature Climate Change, 5(2), 143.

Bennett, D., Reynolds, M., Mullan, D., Izanloo, A., Kuchel, H., Langridge, P. and Schnurbusch, T., (2012). Detection of two major grain yield QTL in bread wheat (Triticum aestivum L.) under heat, drought and high yield potential environments. Theoretical and Applied Genetics, 125(7), pp.1473-1485.

Bhardwaj S. C. (2011). Resistance genes and adult plant rust resistance of released wheat varieties of India. Research Bulletin No. 5: 31 pp. Regional Station, Directorate of Wheat Research, Flowerdale, Shimla 171002 (India).

Bhardwaj S. C., Prashar M., Kumar S., Jain S. K. and Dutta D. (2010). Adult plant 
resistance in some Indian wheat genotypes and postulation of rust resistance genes. Indian Phytopathology, 63(2): 174- 180.

Bhardwaj SC, Prashar M, Jain SK and Datta D. (2005). Lr19 resistance in wheat becomes susceptible to Puccinia triticina in India. Plant Disease 89:1360

Blum, A., Mayer, J., and Golan, G. (1988). The effect of grain number per ear (sink size) on source activity and its water-relations in wheat. Journal of Experimental Botany, 39(1), 106-114.

Boyer, J.S. (1982). Plant productivity and environment. Science. 218: 443-448.

Challinor, A. J., Watson, J., Lobell, D. B., Howden, S. M., Smith, D. R., and Chhetri, N. (2014). A meta-analysis of crop yield under climate change and adaptation. Nature Climate Change. 4, 287-291.

Chen X. Y., Zhao A. J., Li Y. J., Liu Y. P. (2007) Acta Agric. Boreali-Sin., 22 (S2), pp. 1-5

Chhuneja, P., Kaur, S., Singh, K., and Dhaliwal, H. S. (2008). Evaluation of Aegilops tauschii (Coss.) germplasm for Karnal bunt resistance in a screen house with simulated environmental conditions. Plant Genetic Resources. 6, 79-84.

Cossani C.M., Reynolds M. P. (2012) Physiological traits for improving heat tolerance in wheat. Plant Physiology, 160, pp. 1710-1718

Dixon, J., H. J. Braun, and J. H. Crouch. (2009). Overview: Transitioning wheat research to serve the future needs of the developing world. p.1-25 In: J. Dixon, H.-J. Braun, P. Kosina and J.H. Crouch (eds.), Wheat facts and figures 2009. CIMMYT, Mexico, DF.

Eversole, K., Feuillet, C., Mayer, K. F. X. and Rogers J. (2014). Slicing the wheat genome. Science,345(6194): 285-287. Fuentes-Dávila, G., Rajaram, S., and Singh, G. (1995). Inheritance of resistance to Karnal bunt (Tilletia indica Mitra) in bread wheat (Triticum aestivum L.). Plant Breeding. 114, 250-252.

Hansen, J., Sato, M., and Ruedy, R. (2012). Perception of climate change. Proceedings of the National Academy of Sciences, 109(37), E2415-E2423.

Hanson, H., Borlaug, N.E. and Anderson, R.G. (1982). Wheat in the third world. Boulder: Westview Press.

Hede A.R., Skovmand B., Reynolds M.P., Crossa J., Vilhelmsen A.L., Stølen O. (1999) Evaluating genetic diversity for heat tolerance traits in Mexican wheat landraces. Genetic Resource Crop Evolution, 46, pp. 37-45

Huerta-Espino, J., Singh. R.P., German, S., McCallum, B.D., Park, R.F., Chen, W.Q., Bharadwaj S.C. and Goyeau. H. (2011) Global status of wheat leaf rust caused by Puccinia triticina. Euphytica, 179: 143-160.

Joshi, L.M. (1976). Recent contributions towards epidemiology of wheat rusts in India. Indian Phytopathology 29: 116.

Kassa, M.T., Menzies, J.G. and McCartney, C.A. (2015). Mapping of a resistance gene to loose smut (Ustilago tritici) from the Canadian wheat breeding line BW278. Molecular Breeding, 35: 180.

Kulkarni R. N. and Chopra V. L. (1980). Slow-rusting resistance: Its components, nature and inheritance. $Z$. Pflanzenkr. Pflanzenschutz, 87: 562573.

Larkindale J., Knight M. R. (2002) Protection against heat stress-induced oxidative damage in Arabidopsis involves calcium, abscisic acid, ethylene, and salicylic acid. Plant Physiology, 128, pp. 682-695

Lawlor, D. W., and Cornic, G. (2002). 
Photosynthetic carbon assimilation and associated metabolism in relation to water deficits in higher plants. Plant, cell \& environment, 25(2), 275 294.

McIntosh RA, Dubcovsky J, Rogers WJ, Morris C, Xia XC. (2017). Catalogue of gene symbols for wheat: 2017 Supplement Available at https:// shigen.nig.ac.jp/wheat/komugi/ genes/macgene/supplement 2017.pdf

Mishra A. N., Yadav S. R., Shirsekar G. S., Dubey V. G., Kauishal K. and Sai Prasad S. V. (2011). Diversity for resistance to stem and leaf rusts in Indian wheat germplasm. Indian Journal of Plant Genetic Resources. 24(3): 283-291.

Mitra, J. (2001). Genetics and genetic improvement of drought resistance in crop plants. Current Science. 80:758763.

Mitra, M. (1931). A new bunt of wheat in India. Annals of Applied Biology.18:178-179.

Mizrahi, Y., Scherings, S.G., Arad, S.M. and Richmond, A.E., (1974). Aspects of the effect of ABA on the water status of barley and wheat seedlings. Physiologia Plantarum, 31(1), pp.4450.

Moriondo, M., Giannakopoulos, C., and Bindi, M. (2011). Climate change impact assessment: the role of climate extremes in crop yield simulation. Climatic change, 104(3-4), 679-701.

Mujeeb-Kazi, A., Fuentes-Davilla, G., Gul, A., and Mirza, J. I. (2006). Karnal bunt resistance in synthetic hexaploid wheats $(\mathrm{SH})$ derived from durum wheat $\mathrm{x}$ Aegilops tauschii combinations and in some $\mathrm{SH} x$ bread wheat derivatives. Cereal research communications. 34, 1199-1205.

Nath, R., Nath, D., Li, Q., Chen, W. and Cui, X. (2017). Impact of drought on agriculture in the Indo-Gangetic Plain, India. Advances in Atmospheric Sciences. 34: 335.

Nayar S. K., Nagarajan S., Prashar M., Bhardwaj S. C., Jain S. K. and Datta D. (2001). Revised catalogue of genes that accord resistance to Puccinia species in wheat. Res. Bull. No. 3, 48pp. Directorate of Wheat Research, Regional Station, Flowerdale, Shimla, India.

Nayar SK, Jain SK, Prashar M, Bhardwaj SC, Kumar S, Menon MK. (2003). Appearance of new pathotype of Puccinia recondita tritici virulent on Lr9 in India. Indian Phytopathology 56(2):196-198

Nayar SK, Prashar M, Kumar J, Bhardwaj SC, Verma LR, Basandrai AK. (1993). Two new pathotypes of Puccinia recondita tritici with combined virulence for Lr23 and Lr26. Plant Disease Research 9:122-126

Nielsen J, Thomas P (1996) Loose smut. In: Wilcoxson RD, Saari EE (eds) Bunt and smut diseases of wheat: concepts and methods of disease management. CIMMYT, Mexico, pp 33-47 Phytopathology, 29: 1-16.

Pinto S., Chapman S.C, McIntyre C. L., Shorter R., Reynolds M. P. (2008) QTL for canopy temperature response related to yield in both heat and drought environments. In 'Proceedings of the 11th international wheat genetics symposium'.

Pradhan, G. P., Prasad, P. V. V., Fritz, A. K., Kirkham, M. B., and Gill, B. S. (2012). High temperature tolerance in Aegilops species and its potential transfer to wheat. Crop Science, 52(1), 292-304.

Prescott J. M., Burnett P. A., Saari E. E., Ransom J. K., Bowman J. de, Milliano W., Singh R. P. and Geleta A. B. (1986). Wheat diseases and pests: a 
guide for field identification.

Pretorius ZA, Singh RP, Wagoire WW, Payne TS. (2000). Detection of virulence to wheat stem rust resistance gene $\mathrm{Sr} 31$ in Puccinia graminis f. sp. tritici in Uganda. Plant Disease 84:203

Quarrie, S.A., Gulli, M., Calestani, C., Steed, A. and Marmiroli, N., (1994). Location of a gene regulating droughtinduced abscisic acid production on the long arm of chromosome 5A of wheat. Theoretical and Applied Genetics, 89(6), pp.794-800.

Rebetzke, G. J., Botwright, T. L., Moore, C. S., Richards, R. A., and Condon, A. G. (2004). Genotypic variation in specific leaf area for genetic improvement of early vigour in wheat. Field Crops Research, 88(2-3), 179-189.

Reynolds, M. P., and Borlaug, N. E. (2006). Impacts of breeding on international collaborative wheat improvement. The Journal of Agricultural Science, 144(1), 3-17.

Reynolds, M.P., D. Bonnett, S. Chapman, R. Furbank, Y. Manes, D. Mather, and M. Parry. (2011). Raising yield potential of wheat. I. Overview of a consortium approach and breeding strategies. Journal of Experimental Botany. 62:439-452.

Roelfs, A. P. (1992). Rust diseases of wheat: concepts and methods of disease management. Cimmyt.

Sanguineti, M. C., Li, S., Maccaferri, M., Corneti, S., Rotondo, F., Chiari, T., and Tuberosa, R. (2007). Genetic dissection of seminal root architecture in elite durum wheat germplasm. Annals of Applied Biology, 151(3), 291-305.

Singh RP. (1991). International Maize and Wheat Improvement Center (CIMMYT). Pathogenicity variations of Puccinia recondita f. sp. tritici and $P$. graminis f. sp. tritici in wheat- growing areas of Mexico during 1988 and 1989. Plant Disease 75:790-794

Spielmeyer, W., Hyles, J., Joaquim, P., Azanza, F., Bonnett, D., Ellis, M.E., Moore, C. and Richards, R.A., (2007). A QTL on chromosome 6A in bread wheat (Triticum aestivum) is associated with longer coleoptiles, greater seedling vigour and final plant height. Theoretical and Applied Genetics, 115(1), pp.59-66.

Sun Q. X., Quick J. S. (1991) Chromosomal locations of genes for heat tolerance in tetraploid wheat. Cereal Research Communications, 19, pp. 431-437

Tomar S. M. S., Singh S. K., Sivasamy M., Vinod. (2014). Wheat rusts in India: Resistance breeding and gene deployment-A review. Indian Journal of Genetics and Plant Breeding 74(2): 129-56

Trethowan, R. M., and A. MujeebKazi.(2008). Novel Germplasm Resources for Improving Environmental Stress Tolerance of Hexaploid. Wheat. Crop Science. 48:1255-1265.

Tuberosa, R. (2012). Phenotyping for drought tolerance of crops in the genomics era. Frontiers in physiology. 3:347

Verma, V., Foulkes, M.J., Worland, A.J., Sylvester-Bradley, R., Caligari, P.D.S. and Snape, J.W., (2004). Mapping quantitative trait loci for flag leaf senescence as a yield determinant in winter wheat under optimal and drought-stressed environments. Euphytica, 135(3), pp.255-263.

Wardlaw, I., Dawson, I., Munibi, P., and Fewster, R. (1989). The tolerance of wheat to high temperatures during reproductive growth. I. Survey procedures and general response patterns. Australian Journal of Agricultural Research,40(1), 1.

Warham, E. J., Mujeeb-Kazi, A., and Rosas, 
V. (1986). Karnal bunt (Tilletia indica) resistance screening of Aegilops species and their practical utilization for Triticum aestivum improvement. Canadian Journal of Plant Pathology. 8, 65-70.

World agricultural production (2017), United

States Department of Agriculture.
Foreign agricultural service circular series, WAP 12-17.

Xu R., Sun Q., Zhang S. (1996) Chromosomal location of genes for heat tolerance as measured by membrane thermostability of common wheat cv. Hope. Hereditas, 18, pp. 1-3

\section{How to cite this article:}

Omkar M. Limbalkar, Vijay K. Meena, Mandeep Singh and Sunilkumar, V.P. 2018. Genetic Improvement of Wheat for Biotic and Abiotic Stress Tolerance. Int.J.Curr.Microbiol.App.Sci. 7(12): 1962-1971. doi: https://doi.org/10.20546/ijcmas.2018.712.226 